\title{
Investigating True $\beta$-lactam Allergy in the Outpatient Allergy Clinics at a Public Children's Hospital, Ceará, Brazil
}

\author{
Eudiana Vale Francelino ${ }^{1,2 *}$, Sarah Resende Araújo, ${ }^{1,2}$, Janaira Fernandes Severo Ferreira ${ }^{3,4}$, Fabiane Milena de Castro Araújo 3,4 , \\ Kaila Barroso Medeiros Bulgarelli ${ }^{3,4}$, Patrícia Barros Nunes ${ }^{3,4}$, Aparecida Tiemi Nagao-Dias ${ }^{5,2}$ \\ 'Department of Pharmacy, Federal University of Ceará, Fortaleza, Ceará, BRAZIL. \\ 2Rua Capitão Francisco Pedro 1210, Rodolfo Teófilo, CEP: 60.430-370, Fortaleza, Ceará, BRAZIL. \\ ${ }^{3}$ Hospital Infantil Albert Sabin, Fortaleza, Ceará, BRAZIL. \\ ${ }^{4}$ R. Tertuliano Sáles, 544 - Vila Uniao, Fortaleza - CE, 60410-794, BRAZIL. \\ ${ }^{5}$ Department of Clinical and Toxicological Analysis, Federal University of Ceará, Fortaleza, Ceará, BRAZIL.
}

\begin{abstract}
Objective: The aim of the study was to investigate true $\beta$-lactam allergy at a public pediatric hospital. Material and Methods: Children and adolescents with allergy symptoms were referred to the Allergy and Immunology Service, Hospital Infantil Albert Sabin, Fortaleza, Brazil. During the allergist interviews, $\beta$-lactam drug allergy was suspected in 24 patients. Results: Urticaria, angioedema, erythematous macules and papules were the clinical manifestations most frequently reported in 23 patients with immediate reaction. The drugs implicated were amoxicillin (58.3\%), penicillin $(20.8 \%)$, ceftriaxone $(12.5 \%)$ and ampicillin $(8.4 \%)$. The majority of the patients showed negative results for ampicillin, penicillin and ceftriaxone in skin testing and also negative results in Oral Provocation Testing (OPT) to amoxicillin. One patient with clinical history of ceftriaxone allergy showed positive prick test to the drug and negative OPT to amoxicillin. Conclusion: b-lactam drugs are a very useful choice for treatment of bacterial infections in children. In this way, it is reasonable that hypothesis of allergy to those drugs be investigated. For this reason, during consultation, it is necessary
\end{abstract}

that the allergist questions about drug allergy, apart from the original complaint (if it is not directly related to drug allergy). Upon suggestive history, the hypothesis of drug allergy should be ruled out by doing a careful laboratorial and clinical investigation. In order to rationalize the operating and economical costs related to skin testing and OPT, we suggest grouping a number of patients for whom the tests will be performed during a half-day period two to three times a year.

Key words: Allergy, Beta-lactamic, Hypersensitivity, Pediatric, Public hospital. Correspondence

Mrs. Eudiana Vale Francelino, Rua Capitão Francisco Pedro 1210, Rodolfo Teófilo, CEP: 60.430-370, Fortaleza, Ceará, BRAZIL.

Phone: +55(85) 3366-8293

Email: eudiana_vale@yahoo.com.br

DOI: 10.5530/jyp.2019.11.18

\section{INTRODUCTION}

Cases of hypersensitivity to $\beta$-lactam drugs began to be reported in late 1940 and still nowadays are focus of several studies, considering their wide use in clinical practice. ${ }^{1-5}$ Around $10 \%$ to $20 \%$ of the general population are classified as "allergic to penicillin", but the hypothesis is excluded in most of the patients after clinical and laboratorial investigation..$^{2,6,7}$ Abrams et al. ${ }^{8}$ found a very low frequency of positive allergy tests to $\beta$-lactam among patients with suspected allergy to those drugs. Studies have shown that the use of penicillin allergy tests reduces the necessity of prescribing alternative antibiotic drugs, which are more expensive, less effective and at risk of adverse events. ${ }^{9,10}$

Drug allergy is in general classified into four types of hypersensitivity according to the Gell and Coombs classification. The most frequent clinical manifestations related to drug allergy are included in type I (immediate) or type IV (delayed) reactions. ${ }^{11}$ The type I hypersensitivity occurs few minutes to $1 \mathrm{hr}$ after intake of the drug and is mediated by IgE antibodies, basophils and mast cells. Angioedema, pruritus, urticaria and anaphylaxis are the most common clinical manifestations that occur in this type of reaction. ${ }^{12,13}$ Laboratorial diagnosis includes specific IgE, identification by the CAP-IgE test, basophil degranulation by the BAT-test, besides prick, intradermal and oral provocation testing. The type IV occurs after $24 \mathrm{~h}$ of the drug administration and is characterized by different types of clinical manifestations such as contact dermatitis, maculopapular exanthema, acute generalized pustulosis, Steven-Johnson syndrome, toxic epidermal necrolysis. ${ }^{14}$ Laboratorial diagnosis includes patch, intradermal, oral provocation testing (the last ones are contraindicated when clinical manifestations are severe). The suspected type of hypersensitivity drives the type of test to be used. Beta-lactam drugs may be involved in all types of hypersensitivity reactions. ${ }^{12,13}$ These drugs are prescribed to children in the context of bacterial infections. Unfortunately, viral infections can be misdiagnosed being erroneously treated with those drugs. The frequency of a true drug allergy can vary from 7 to $60 \% \cdot{ }^{15-17}$ Our study aims to confirm or to exclude true drug allergy among patients with history of $\beta$-lactam allergy in the allergy outpatient service at a public children's hospital.

\section{MATERIALS AND METHODS}

The research was approved by the Research Ethics Committee of the Hospital Infantil Albert Sabin, Fortaleza, Ceará, Brazil (process number 944.331).

\section{Study Design}

A prospective study (from 2015 to 2018) was conducted in the allergy outpatient service at a public children's hospital, Fortaleza, Ceará, Brazil. Univariate analysis was used to describe every single variable (sex, timing of reaction, clinical manifestations, drugs, number of tests, test results), employing relative frequencies and numbers, besides the age range. 


\section{Patients}

Children and adolescents up to 18 years of age, at the allergy outpatient service, Hospital Infantil Albert Sabin, HIAS, Fortaleza, Ceara, Brazil, presenting suspected drug allergy to b-lactam drugs were included in the study. Signed informed consent term was provided by the patient or his/her legal guardian after explanation of the project. The children were referred to the outpatient allergy service due to allergic diseases such as contact dermatitis, atopic dermatitis, asthma, allergic rhinitis, food allergy. During the consultation with the allergist, several questions were done regarding the different types of allergy. When drug allergy was suspected, a detailed description of the clinical history was taken by applying a questionnaire adapted from Demoly et al. ${ }^{18}$ The skin testing was scheduled according to the type of reaction, that is, prick and intradermal tests for immediate reactions and epicutaneous test for delayed reactions. If results in the prick and intradermal tests were negative, oral provocation testing was scheduled. The inclusion criteria were those children and adolescents up to 18 years of age with allergic symptoms. The exclusion criteria were those children and adolescents up to 18 years of age who did not present suspected b-lactam allergy during the allergist consultation.

The test was conducted on three parts: Day one - Prick test and intradermal test for pencilin, ampicillin and ceftriaxone. Day two (after one week) - Oral Provocation Testing (OPT). Day Three (after one week after OPT) - reavaliation for late reactions. Penicillin at $10,000 \mathrm{IU} / \mathrm{mL}^{19}$ was used for the prick and intradermal testing. Ampicillin at $20 \mathrm{mg} / \mathrm{mL}$ and ceftriaxone at $2 \mathrm{mg} / \mathrm{mL}$ were also used. ${ }^{20}$ The procedure for immediate skin testing was followed according to Torres et al. ${ }^{21}$ and Malaman et al. ${ }^{22}$ A negative ( $0.9 \%$ saline solution) and a positive control (histamine solution at $10 \mathrm{mg} / \mathrm{mL}$, FDA Allergenic, USA) were used in the prick tests. For the intradermal tests, only the negative control was used. ${ }^{23,24}$
Positive results were considered when a papule was greater than $3 \mathrm{~mm}$ in diameter in comparison to the negative control. ${ }^{23,24}$ Upon negative results, intradermal testing was performed. All readings were performed after 15-20 min. Upon negative results, Oral Provocation Testing (OPT) was scheduled. Tests were not performed in patients undergoing corticosteroid or immunosuppressive therapy that could not be discontinued or in case of suspected infectious disease at the time of testing.

The OPT was performed with amoxicillin suspension at $25 \mathrm{mg} / \mathrm{kg} / \mathrm{dose}$. The test was divided into 5 steps, according to Aberer et al.1) placebo (5 mL water) 2) $10 \%$ of the usual dose; 3) $20 \%$; 4) $30 \%$ and 5) $40 \%$. The final sum of the cumulative dose was $100 \%$, which corresponded to the therapeutic dose. ${ }^{25}$ Upon a negative result, the patient received the usual dose of the drug, that is $25 \mathrm{mg} / \mathrm{kg} /$ dose, $12 / 12 \mathrm{hrs}$, at home, for 5 days and a reassessment was made at the outpatient clinic after 1 week. In this case, the person in charge of the child should observe if any skin reaction would appear during that period.

The procedure for the epicutaneous tests was done according to Barbaud. ${ }^{26}$ Finn chambers were filled with the drugs previously dissolved in $10 \%$ petrolatum and applied on the dorsum of the patient. Readings were performed after $48 \mathrm{~h}, 72 \mathrm{~h}, 96 \mathrm{~h}$ and on the $7^{\text {th }}$ day. ${ }^{27}$

\section{RESULTS}

Twenty-four pediatric patients aged 3 to 17 years old (13 girls (54.2\%) and 11 boys ( $45.8 \%)$ ) were evaluated for beta-lactam allergy. The reactions occurred between $10 \mathrm{~min}$ and $1 \mathrm{~h}$ after drug intake in 19 out of 24 patients (79.1\%), between 1 to $2 \mathrm{~h}$ in 4 patients (16.7\%) and after $24 \mathrm{~h}$ in 1 patient $(4.2 \%)$. Urticaria, angioedema, erythematous macules and papules were the clinical manifestations most frequently reported in patients with immediate hypersensitivity to $\beta$-lactams (Table 1). Residual lesions were present in late hypersensitivity (Table 1). The drugs

\begin{tabular}{|c|c|c|c|c|}
\hline Clinical manifestations & Drug & $\begin{array}{l}\text { Timing of } \\
\text { reaction }\end{array}$ & $\begin{array}{c}\text { Number of } \\
\text { patients }\end{array}$ & $\begin{array}{c}\text { Frequency } \\
\text { (\%) }\end{array}$ \\
\hline \multicolumn{5}{|l|}{ Diffuse erythematous plaques } \\
\hline \multicolumn{5}{|l|}{ Urticarial rash } \\
\hline Angioedema & penicillin & $30 \mathrm{~min}$ to $1 \mathrm{~h}$ & 5 & 20.8 \\
\hline \multicolumn{5}{|l|}{ Urticaria } \\
\hline \multicolumn{5}{|l|}{ Redness } \\
\hline \multicolumn{3}{|l|}{ Angioedema } & 2 & 8.4 \\
\hline \multicolumn{5}{|c|}{ Erythematous macules in trunk and legs } \\
\hline \multicolumn{5}{|c|}{ Urticaria and periorbital and facial angioedema } \\
\hline \multicolumn{5}{|l|}{ Urticaria and rash } \\
\hline \multicolumn{5}{|c|}{ Facial / lip and periorbital angioedema } \\
\hline \multicolumn{5}{|l|}{ Diffuse maculopapular rash } \\
\hline Generalized urticaria & amoxicillin & $10 \mathrm{~min}$ to $1 \mathrm{~h}$ & 14 & 58.3 \\
\hline \multicolumn{5}{|c|}{ Red spots and generalized urticaria } \\
\hline \multicolumn{5}{|l|}{ Hyperemia and facial edema } \\
\hline \multicolumn{5}{|l|}{ Eye pruritus / red spots } \\
\hline \multicolumn{5}{|l|}{ Exanthema } \\
\hline \multicolumn{5}{|l|}{ Eyelid / facial edema } \\
\hline & & & & 8.3 \\
\hline \multicolumn{5}{|l|}{ Anaphylactic reaction } \\
\hline Residual lesions & ceftriaxone & after 5 days & 1 & 4.2 \\
\hline Total (patients) & & & 24 & \\
\hline
\end{tabular}




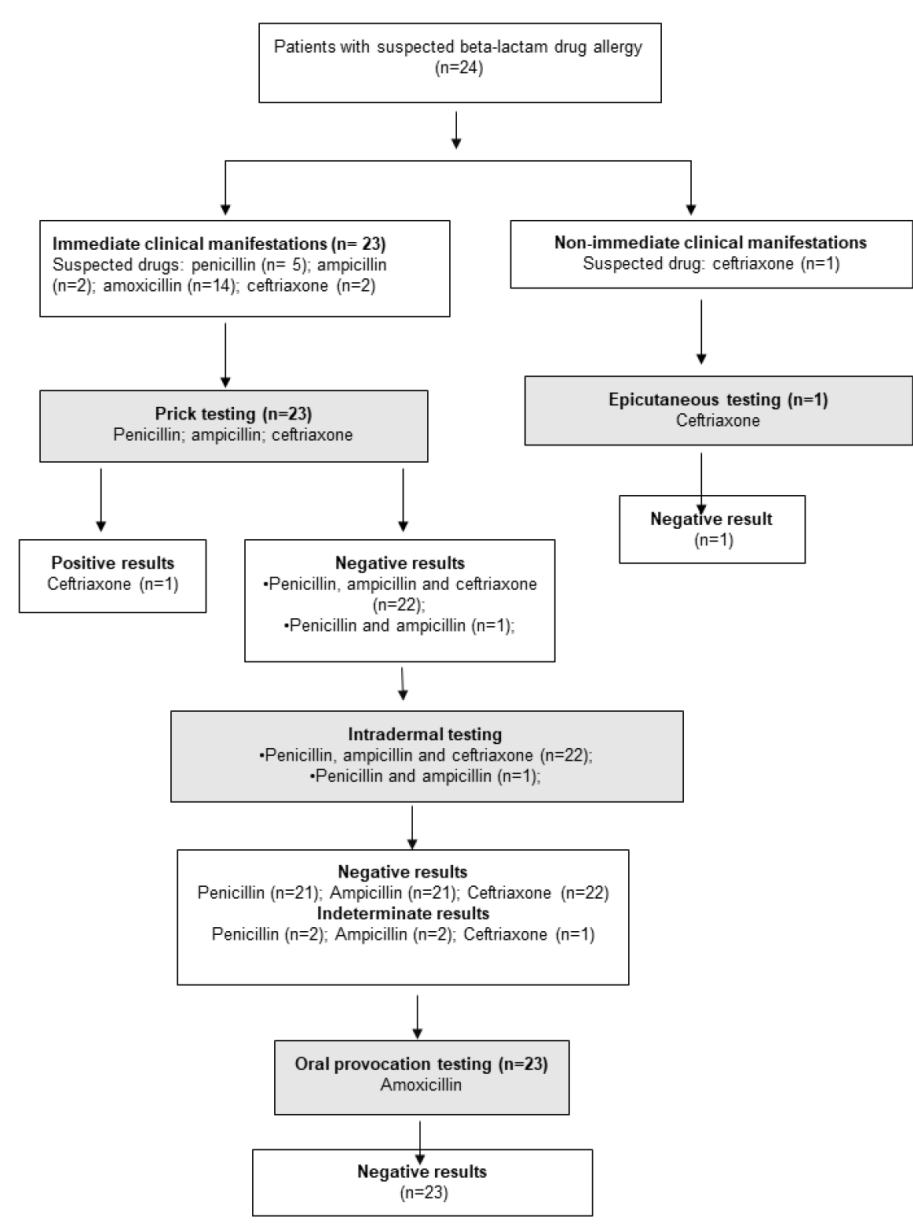

Figure 1: Investigation of $\beta$-lactam allergy in pediatric patients with suspected beta-lactam drug allergy.

most implicated were amoxicillin (58.3\%), penicillin (20.8\%), ceftriaxone (12.5\%) and ampicillin (8.4\%).

The mean time between the drug adverse reaction and the allergist consultation was 2 years and 7 months (15 days to 13 years).

Immediate skin testing with penicillin, ampicillin and ceftriaxone were conducted in 23 patients (Figure 1). All of them presented negative skin prick testing to ampicillin and penicillin (100\%). Twenty-two out of 23 patients $(95.6 \%)$ showed negative skin prick testing to ceftriaxone. Intradermal testing was performed with the same drugs after negative prick results. Twenty-one out of 23 patients (91.3\%) showed negative results in intradermal testing with penicillin and ampicillin. All patients were submitted to the oral provocation test with amoxicillin and showed negative results (100\%).

One patient with a previous history of allergic rhinitis and probable asthma showed positive skin prick testing ( 1 out of 23 patients, $4.3 \%$ ) to ceftriaxone (papule with erythema, 4 x $5 \mathrm{~mm}$ diameter) but negative skin prick testing to ampicillin and penicillin. Intradermal testing with these drugs resulted indeterminate to ampicillin and negative to penicillin. Neither intradermal testing nor OPT for ceftriaxone was performed, once the prick test with the drug resulted positive. The child showed negative OPT to amoxicillin, excluding the hypothesis of allergy to amoxicillin. The first clinical manifestations occurred when she was 7 months old few hours after ceftriaxone administration. At that time, according to her mother, she has been hospitalized due to an episode of pneumonia and few hours after the $3^{\text {rd }}$ day of ceftriaxone therapy, the child presented cough, dyspnea and erythema. The clinical manifestations disappeared 2 hrs after the use of anti-allergy medication. Nine months later, the patient had a new hospitalization due to an episode of tonsillitis. She was treated with ampicillin. During the hospitalization, the patient had episodes of suffocation, cyanosis and facial edema; nonetheless, it was not possible to establish a temporal association with the drug exposure. Allergy to penicillin-chemically related drugs was ruled out after negative skin and intradermal test for ampicillin and penicillin and negative oral challenge with amoxicillin. Improvement of the symptoms occurred after administration of corticosteroids and antihistamines.

The epicutaneous test with ceftriaxone was performed in one patient and the results were negative after $48 \mathrm{~h}, 72 \mathrm{~h}, 96 \mathrm{~h}$ and 7 days. The patient had a clinical history of residual lesions 5 days after drug intake (1 out of 24 patients, $4.2 \%)$.

\section{DISCUSSION}

Some factors are essential to raise the hypothesis of drug allergy, such as the nature of drug, degree of exposure (dose, duration, frequency), route of administration and cross-reactivity to other chemical groups. Patient's characteristics such as age and sex, genetic factors (the HLA system, cytokine and enzyme polymorphisms) may influence the rate of drug allergy although there is no conclusive evidence. ${ }^{28}$ Atopy is not related to drug allergy, but when it occurs, for instance, in chronic asthma, the clinical manifestations may be more severe. ${ }^{13}$ Epstein-Barr virus, human immunodeficiency virus, herpes virus 6 may predispose the patient to drug hypersensitivity..$^{29,30}$

During consultation, it is important for the allergist to question about drug allergy, apart from the original complaint (if it is not related to drug allergy). In the period of the study (2015 - 2018), 24 patients with suspected allergy to $\beta$-lactam drugs were investigated.

Allergy to $\beta$-lactams is observed mostly in children; ${ }^{31}$ nonetheless, the frequency of true drug allergy to the drugs has been overestimated. ${ }^{32,33}$ One of the main confounding factors is viral infection. ${ }^{34}$

To rule out $\beta$-lactam allergy is important in order to avoid the use of alternative therapeutics based on broad-spectrum antibiotics such as vancomycin, quinolones. The main purpose is to reduce possible complications caused by indiscriminate use of antimicrobial drugs, such as Clostridium difficile infections and vancomycin-resistant Enterococci. ${ }^{35}$ Several publications have shown that the use of skin tests can exclude $\beta$-lactam allergy in $90 \%$ of patients, which leads to a rational use of antibiotic therapy. ${ }^{36}$

By the fact that the number of patients with suspected drug allergy was relatively low, we decided to minimize operating and economical costs by conducting the skin testing in groups of 10 patients during a halfday period three times a year. The strategy rationalized the procedure making it possible to be operationalized without high expenses at a public pediatric hospital.

In relation to the child who showed hypersensitivity to ceftriaxone, the positive prick test confirmed the hypothesis of drug allergy. Ceftriaxone is a third-generation cephalosporin which presents different side chain to penicillin. Therefore, it would be rather rare to bear any cross-reactivity between the chemical structures. ${ }^{37}$ On the other hand, ampicillin and penicillin are chemically related to each other. For this reason, upon negative prick testing with ampicillin and penicillin and indeterminate and negative intradermal testing with ampicillin and penicillin, respectively, we found reasonable to perform OPT with amoxicillin.

\section{CONCLUSION}

Beta-lactam drugs are a very useful choice for treatment of bacterial infections in children. In this way, it is reasonable that hypothesis of allergy 
Francelino, et al.: Investigating True $\beta$-lactam Allergy in the Outpatient Allergy Clinics at a Public Children’s Hospital, Ceará, Brazil

to those drugs be investigated. For this reason, during consultation, it is necessary that the allergist questions about drug allergy, apart from the original complaint (if it is not directly related to drug allergy). Upon suggestive history, the hypothesis of drug allergy should be ruled out by doing a careful laboratorial and clinical investigation. In order to rationalize the operating and economical costs related to skin testing and OPT, we suggest grouping a number of patients in whom the tests will be performed during a half-day period two to three times a year.

\section{ACKNOWLEDGEMENT}

The authors thank the HIAS health team.

\section{CONFLICT OF INTEREST}

The authors declare no conflict of interest.

\section{ABBREVIATIONS}

BAT-test: Basophil Activation Test; CAP-IgE: cellulose fluorescent assay-IgE; OPT: Oral Provocation Test.

\section{REFERENCES}

1. Felix MMR, Kuschnir, FC. Alergia à penicilina: aspectos atuais: Adolesc Saude. 2011;8(3):43-53.

2. Macy E, Ngor EW. Safely diagnosing clinically significant penicillin allergy using only penicilloyl-poly-lysine, penicillin and oral amoxicillin. J Allergy Clin Immunol Pract. 2013;1(3):258-63.

3. Viana JC, Abreu C, Gomes ER. Hipersensibilidade medicamentosa em crianças de idade pré-escolar. Nascer e Crescer [Internet]. 2018;25(1):15-21. Available from: <http://www.scielo.mec.pt/scielo.php?script=sci_arttext\&pid=S0872075 42016000100003\&lng=pt\&nrm=iso $>$.

4. Norton AE, Konvinse K, Phillips EJ, Broyles AD. Antibiotic allergy in pediatrics. Pediatrics. 2018;141(5):e20172497.

5. Vyles D, Chiu A, Routes J, Castells M, Phillips EJ, Kibicho J, et al. Antibiotic Use After Removal of Penicillin Allergy Label. Pediatrics. 2018;141(5):e20173466.

6. Borch JE, Andersen KE, Bindslev-Jensen C. The prevalence of suspected and challenge-verified penicillin allergy in a university hospital population. Basic Clin Pharmacol Toxicol. 2006;98(4):357-62.

7. Joint Task Force on Practice Parameters American Academy of Allergy, Asthma and Immunology; American College of Allergy, Asthma and immunology, Joint Council of Allergy, Asthma and immunology. Drug allergy: an updated practice parameter. Ann Allergy Asthma Immunol. 2010;105(4):259-73.

8. Abrams EM, Wakeman A, Gerstner TV, Warrington RJ, Singer AG. Prevalence of beta-lactam allergy: a retrospective chart review of drug allergy assessment in a predominantly pediatric population. Allergy Asthma Clin Immunol. 2016;12(1):59

9. Schafer JA, Mateo N, Parlier GL, Rotschafer JC. Penicillin Allergy Skin Testing: What Do We Do Now?. Pharmacotherapy. 2007;27(4):542-5.

10. Trubiano JA, Thursky KA, Stewardson AJ, Urbancic K, Worth LJ, Jackson C, et al. Impact of an Integrated Antibiotic Allergy Testing Program on Antimicrobial Stewardship: A Multicenter Evaluation. Clin Infect Dis. 2007;65(1):166-74.

11. Demoly P, Adkinson NF, Brockow K, Castells M, Chiriac AM, Greenberger PA, et al. International Consensus on drug allergy. Allergy. 2014;69(4):420-37.

12. Solensky R. Drug desensitization. Immunol Allergy Clin North Am. 2004;24(3):425-43.

13. Ditto AM. Drug allergy. Part A: Introduction, epidemiology, classification of adverse reactions, immunochemical basis, risk factors, evaluation of patients with suspected drug allergy, patient management considerations. In: Grammer LC, Greenberger PA, eds. Patterson's Allergic Diseases. $7^{\text {th }}$ ed. Lippincott Williams and Wilkins. 2009;238-75.

14. Ghosh K, Banerjee G, Ghosal AK, Nandi J. Cutaneous drug hypersensitivity: immunological and genetic perspective. Indian J Dermatol. 2011;56(2):137-44.

15. Romano A, Torres MJ, Fernandez J, Vega JM, Mayorga C, Garcia J, et al. Allergic reactions to ampicillin. Studies on the specificity and selectivity in subjects with immediate reactions. Clin Exp Allergy. 1997;27(12):1425-31.

16. Zambonino MA, Torres MJ, Muñoz C, Requena G, Mayorga C, Posadas T, et al. Drug provocation tests in the diagnosis of hypersensitivity reactions to non-steroidal anti-inflammatory drugs in children. Pediatr Allergy Immunol. 2013;24(2):151-9.

17. Zambonino MA, Corzo JL, Muñoz C, Requena G, Ariza A, Mayorga C, et al. Diagnostic evaluation of hypersensitivity reactions to beta-lactam antibiotics in a large population of children. Pediatr Allergy Immunol. 2014;25(1):80-7.

18. Demoly P, Kropf R, Bircher A, Pichler WJ. Drug hypersensitivity: questionnaire. Allergy. 1999;54(9):999-1003.

19. Brockow K, Garvey LH, Aberer W, Atanaskovic-Markovic M, Barbaud A, Bilo MB et al. Skin test concentrations for systemically administered drugs - an ENDA/ EAACI Drug Allergy Interest Group position paper. Allergy. 2013;68(6):702-12.

20. Brazil. Ministério da saúde. Testes de sensibilidade à penicilina - Manual. Brasília: Coordenação Nacional de DST / AIDS. Secretaria de Políticas de Saúde, Ministério da Saúde. 1999.

21. Torres MJ, Blanca M, Férnandez J, Romano A, Weck A, Aberer W, et al. Diagnosis of immediate allergic reactions to beta-lactam antibiotics. Allergy. 2003;58(10):961-72.

22. Malaman MF, Rodrigues AT, Felix MM, Menezes UP, Tanno LK, Nunes IC, et al. Recomendações para o diagnóstico das reações de hipersensibilidade imediatas aos antibióticos beta-lactâmicos. Rev Bras Alerg Imunopatol. 2011;34(6):257-62

23. Motta AA, Kalil J, Barros MT. Testes cutâneos. Rev Bras Alerg Imunopatol 2005;8:73-83.

24. Kranke B, Aberer W. Skin Testing for IgE-Mediated Drug Allergy. Immunol Allergy Clin N Am. 2009;29(3):503-16.

25. Aberer W, Bircher A, Romano A, Blanca M. Drug provocation testing in the diagnosis of drug hypersensitivity reactions: general considerations. Allergy. 2003;58(9):854-63.

26. Barbaud A. Place of drug skin tests in investigations systemic cutaneous drug reactions. In: PICHLER, W. J. Drug hypersensitivity. $1^{\text {st }}$ ed. Basel: Karger AG. 2007;366-79

27. Barbaud A. Skin testing in delayed reactions to drugs. Immunol Allergy Clin N Am. 2009;29(3):517-35.

28. Mirakian R, Leech SC, Krishna MT, Richter AG, Huber PA, Farooque S, et al. Standards of care committee of the British society for allergy and clinical immunology. Management of allergy to penicillins and other beta-lactams. Clin Exp Allergy. 2015;45(2):300-27.

29. Ozcan D, Seckin D, Bilezikci B, Arslan H. The role of human herpesvirus-6, Epstein-Barr virus and cytomegalovirus infections in the etiopathogenesis of different types of cutaneous drug reactions. Int J Dermatol. 2010;49(11):1250-4.

30. Chovel-Sella A, Ben TA, Lahav E, Mor O, Rudich H, Paret G, et al. Incidence of rash after amoxicillin treatment in children with infectious mononucleosis. Pediatrics. 2013;131:1424-7.

31. Gomes ER, Brockow K, Kuyucu S, Saretta F, Mori F, Blanca-Lopez N, et al. Drug hypersensitivity in children: report from the pediatric task force of the EAACl Drug Allergy Interest Group. Allergy. 2016;71(2):149-61.

32. Caubet JC, Eigenmann PA. Managing possible antibiotic allergy in children. Curr Opin Infect Dis. 2012;25(3):279-85.

33. Solensky R, Khan DA. Evaluation of antibiotic allergy: the role of skin tests and drug challenges. Curr Allergy Asthma Rep. 2014;14(9):459.

34. Warrington R, Silviu-Dan F. Drug allergy. Allergy Asthma Clin Immunol. 2011;7 Suppl 1:S10.

35. Solensky R. Penicillin allergy as a public health measure. J Allergy Clin Immunol. 2014;133(3):797-8.

36. Park MA, Mcclimon BJ, Ferguson B, Markus PJ, Odell L, Swanson A, et al. Collaboration between allergists and pharmacists increases beta-lactam antibiotic prescriptions in patients with a history of penicillin allergy. Int Arch Allergy Immunol. 2011;154(1):57-62

37. Pegler S, Healy B. In patients allergic to penicillin, consider second and third generation cephalosporins for life threatening infections. BMJ. 2007;335(7627):991.

Article History: Submission Date : 08-06-2018; Revised Date : 03-08-2018; Acceptance Date : 03-10-2018.

Cite this article: Francelino EV, Araújo SR, Ferreira JFS, Araújo FMC, Bulgarelli KBM, Nunes PB, Nagao-Dias AT, et al. Investigating True $\beta$-lactam Allergy in the Outpatient Allergy Clinics at a Public Children's Hospital, Ceará, Brazil. J Young Pharm. 2019;11(1):88-91. 